\title{
IMPROVEMENT OF TEACHERS QUALIFICATIONS
}

\section{OLENA DOBROTVOR}

https://doi.org/10.35945/gb.2017.04.013

PhD in Pedagogical Sciences,

Associated Professor of National Aviation University, Institute of the Humanities, Ukraine

\section{KEYWORDS: CONTINUING PROFESSIONAL EDUCATION, ADVANCED TRAINING, TEACHINGS STAFF, REFLECTION}

Introduction. The modernization of qualifications improvement in Ukraine, particularly in education, identified as priority at the state level. The Decree of the President of Ukraine "About the National Strategy for Development of Education in Ukraine for the period till 2021" dated June 25, 2013 №344 / 2013 indicated the need to develop “improving training, retraining and educational, scientific and educational cadres education system improve their administrative culture " (http://zakon2.rada.gov.ua/laws/show/344/2013).

The European integration processes and signing of Bologna Declaration requires from Ukraine the changes in the area of education, particularly the implementation of the principle of "lifelong learning", the ECTS assessment of learning outcomes, coordination of the level of qualification. In accordance to it today there is an active discussion of specific ways in order to update forms and methods of training, including qualification's improvement of teachers. Organizers and participants of the training program note some progress towards improving the quality of these processes, but there are issues requiring further special research and solutions.

The reorientation of the formal training program focuses on practical development of teachers abilities to analyze their own professional activity, to determine the actual direction of growth, fix particular results in real situations. These problems of higher educational institutions with III-IV levels of accreditation are very actual.

The aim of the article is in theoretical justification of conditions due to productive updating of teacher's qualifications improvement process in universities. Our task is to clarify the basic problems of training teachers through analyzing a scientific and technical literature (and other available sources); a definition and theoretical foundation of conditions in effective teaching of modern university lecturers; to clarify the methods of diagnostics of lecturer's professional development.

Theoretical analysis of the scientific and methodical literature of advanced training. In a specific literature we find the results of theoretical research and solutions to educational problems of improving professional skills of educators. For example: improving the efficiency of an educational process at the faculties of improving the qualification training (Borisov N., Demchuk V.), self-education (Novichkova V.); there are also some studies dedicated to the institutions elaborating teachers (Prokopenko L.); researching the differentiation of learning the outcomes of certification (Tishchenko T.), organizational and pedagogical conditions (Chehodayev M.), informational security (Sknar V.). Theory and practice of various aspects of pedagogical control is considered by Aleksyuk A., Arhanhelskiy S., Bulah I., Balyubash Ya., Dmytrenko H., Korsak K., Oliynyk V., Pidlasiy I., Filonchuk I. and others.

The generalized scientific research about relationship of theoretical and practical training is important for our work, as well as a postgraduate training system integrity, which has its assignments, contents, methods and forms, ways of a development [Protasova N., 1999; Rozenberh A., 1998]. To analyze this system and solve the existing problems it should be noted that the process of training - is the process which intensificates a becoming of social maturity of teacher's individuality. In according to this it is a change of any of the sides, aspects of his career and his professional adjustments. However, as noted by teachers themselves, "teacher's training courses give only the necessary minimum of knowledge. As a practice shows these courses are formal if they are constantly not updated by self-education [Radul V., 1997]. Self-development, self-improvement of an individual and its potential are main factors of success, efficiency of reforms in various fields, especially in educational one. Professional selfimprovement as a specific kind of professional activity is an integral part of training and retraining specialists.

However, in special studies [Konovalova L., 2012] we find the systematization of major contradictions in educational practices that point to a lack of readiness of teachers on a level of self-mastery of methodical knowledge, skills, reflection of their own professional activity.

In analytical articles it is stated that theory and practice of pedagogical control in a system of training managing and teaching staff in education needs a special attention. The main reasons in this direction are: "an absence of governmental and industrial standards in training of a teaching staff; contingent features; low budget of a study time; deficiency of a systematic approach to the problem" [Oliynyk V., 2006].

In guidelines developed by specialists [Polozhennya, 2005] the concept of "diagnosis" is considered, its structure and content components to improve the training of senior teaching staff in education are defined. In general, as indicated by authors of the development, the existing control system is improved, increased objectivity, reliability and validity of results through introducing a clear criteria of diagnostics: individual and group educational achievements of students, individual and group progress of training and sated conformity of all indicators according to European scale ECTS (realization of a decision of a Board Ministry of Education and Science of Ukraine from 24.04.2003 bringing the knowledge evaluation system to ECTS level). Published teaching materials are universal and can be used in various forms of organization of training of teaching staff in educational system, including a 
credit-module organization of educational process [Oliynyk V., 2007].

However, innovative approaches of a design of the structure and content of pedagogical control system in our opinion lays not in credit-modular system of educational process in terms of blended learning, as noted by Lyahots'ka L. [Lyakhots'ka L., 2012]. The lack of analyzed sources with specifics of control of teaching adults should be noted. In our view, the performance of adult education, the real training needs a systemic approach in learning content and its organizational and methodological support, in which a diagnostics is an integral part.

Terms of productive updating the process of training teachers in modern universities. The analysis of reports of Ukrainian nationwide scientific conferences in 2013 provides the opportunity to organize the basic needs of practitioners, which are aimed to improve training locally. In particular, important for our search is requests to determine the theoretical foundations and development of technologies for professional development of teachers in postgraduate education, to search semantic and effective ways of updating content and technologies of professional development of teachers in postgraduate education.

Basing on these facts, the main problem of training of teachers from all university departments can be fixed - a widespread practice of operating conventional circuit of training: gaining new knowledge on lectures, seminars and workshops; diagnosing the effectiveness of such programs using a familiar assessment scale (five point scale or differentiated by ECTS credit system), credit measures, progress reports, term papers etc. After completing courses a teacher returns to his job and should be able to optimize it.

To determine a necessary and sufficient conditions to achieve reality and not a formal training the help of a scientific knowledge in andragogics and trainer's conclusions of Tolyattinska Academy of Management (Russia) in relation to work with adults in specific situations [Stepanova Y., 2004, p. 71]:

1. Adult learning cannot impose: adults must be willing to learn (linked to career growth).

2. Adults learn during work process (obviously it is ineffective to read lectures for specialists for their further development; this method does not allow solving the main task - changing skills).

3. Adult learning should focus on the problems. Adults have the material with which they work every day, so it is needed during the training to enable adults to acquire experience in solving critical problems.

4. Adults to learn hampered severely their previous experience. While training it is important to think abstractedly and forget about the functional point.

5. Adults learn best under informal circumstances, in separation with issues/ problems (better in another city).

6. Adults should not be evaluating: tests and exams are unacceptable.

Thus, according to these principles it is about to form the conditions of effective teacher's training in universities. The professionals should be stratified (not to evaluate on the "outside"), should diagnose not only knowledge, but also ways of working, to record changes in the training according to specific of personal goals. As a result, it is necessary to answer the question "Did a teacher change his/her qualification?" no system of formal evaluation can answer this question.

Guidelines to fix changing skills as a result of postgraduate education. By definition of $G$. Shchedrovitsky "reflection - is an idea in mind of what we do and how" [Putevodytel', 2003, p. 43]. Psychologists define the reflection (from latin reflexio - reversing) as a process of self-discovery. Reflection can be recognised as a learning element that forms a special relationship of the participants to the subject of own activity (Zinchenko O., Ivanov A., Pometun O., Trubacheva S.).

To operate successfully in the future with problematic situations, we must not only remember our previous situations, bit also ask reflexive questions (such as "Which concept is used?", "What are the ways to act?", "Will those ways that we already work?"). Organizers involve participants in the process of reflection that leads to the development of their understanding, because it provides a conscious work on what succeeded. Organizers and participants on a basis of specifically planned reflexive analysis can see new for themselves directions in solving problems and planning special events and also determine their own way of productive activity.

According to the theoretical and methodological basis of determining a semantic reflection that was revealed by a founder of developmental education (Davydov V.), a pedagogical aim is not realized in transmitting knowledge and thinking skills, but in development of a need and understanding skills that form the basis of theoretical knowledge and practical thinking. Only during the presentation of understanding and evaluating of what the other made, comes an opportunity to see yourself "from the side ", due to get an objective picture of your work. Thus reflection provides a self-understanding and you own activity [Shchedrovitsky G., 1975]. Thus prospective reflection undergoes that what is possible, modal reflection undergoes - that what is needed to be done. These steps are outgoing and preparing thinking activity. And retrospective reflection covers that what was able to be done. The process of understanding of the own activities, yourself in collaboration with other activities, variety of options and consequences based on the forms that specifies an organizer of reflection.

In our view, given reflection's learning effect associated with the occurrence of psychological detachment: the participant is able to see his activity (and himself) as the subject, having an opportunity to fix errors, inaccuracies, seek for a greater efficiency. Davydov V., Neverkovych S., Samoukyna N. confirm the unique and creative reflection function that causes qualitative changes in a process of thinking of the participants, in their personality.

Examples:

1. Do I use active exercise / workout? If so, which ones?

2. What can I do to regain focus and increase interest?

3. What are three improvements I can make to the links given in my course?

4. What evaluation methods are able to open me and the students a comprehensive picture of what they can achieve?

Due to organized understanding there is an intense "growth", new skills are formed and the creative potential of 
individuality is developing. Thus, reflective tasks, questions and discussions serve as effective mechanism of real changing in career that is totally relevant to the principles of adult (professionals) education.

To explain more clearly, the feedback from colleagues makes it possible to objectively reflect on teaching practices and prove their own professional achievements, be open to the criticism and recommendations, plan more effective approaches to new classroom situations. This is how the International Pedagogical Club "Professional Portfolio" is organized. It is the association of teachers of higher and secondary educational establishments whose aim is to share their professional experience, accumulate and preserve the best teaching methods approved in real life classrooms. (The Club was initiated by Olena Dobrotvor and Alexander Skakunov, the author of IT-education project "Zero to Hero". Since May 14, 2016 the project has registered 60 participants from different regions of Ukraine as well as Slovakia, Poland, Germany, Bulgaria, Georgia (https://www.facebook.com/ groups/234752410224796/?fref=ts). The organizers of the Club launched a series of training workshops and alternative so called anti-conferences named "Self-Teacher».

In the given format of pedagogical discussions club members inform colleagues on the ways of improving teaching-learning practices and demonstrate working techniques and ways of evaluating training results. The following issues have already been discussed:

- Critical thinking of the young people, their ideas on training and lectures;

- Learning a foreign language by "ear-mouth-eyes-hand method";

- Visualization cognitive activity of students in the classroom
Academic integrity;

A workshop on poetry for everybody;

Establishing criteria for assessment of student's achievements;

Probability theory in the interaction between children and students.

Conclusions. The use of reflection as a tool for organizing training of university lecturers displays the external position in relate to a past experience and the future that is being projected. A guarantee of origins in understanding teachers is a plan alone or a project which can be created only by analyzing and understanding of activity which was made earlier. Using terminology of an acknowledged methodologist Shchedrovitsky G., a lecturer must take the "reflexive position" of a leader in relate to his previous position. This "reflective way-out" provides a "reflexive knowledge" that formed relative to the knowledge that has been processed in the previous position. Thus, reflection provides a stable selfdevelopment of the teacher's individuality.

Thus, the effectiveness of training programs for teachers of university departments depends fully on the ability of all participants to organize reflection. Accordingly, there is a need to develop guidelines due to design issues with special construction (What should be done (individual; in group) according to the program? What can I do in accordance with training, skills, career guidance? Why my goals do not coincide with the goals of the organizers?), to calculate the time for answer, to enhance the will of the participants. Also it should be kept in mind that elements of a natural reflection can be traced in the life of every person. So the challenge is in spreading the practice of systematic and deliberate action in the area of post-graduate education.

\section{REFERENCES:}

1. Protasova N. Teoretyko-metodychni osnovy funktsionuvannya systemy pislyadyplomnoyi osvity pedahohiv $v$ Ukrayini / Avtoref. dys. d. ped. nauk. - K., 1999. - 38 s. - S. 12.

2. Rozenberh A. Aktual'ni problemy teoriyi i praktyky pislyadyplomnoyi osvity kerivnykh i pedahohichnykh kadriv / Mat. zvitnoyi nauk. konf., 5-6 bereznya 1998r. - Ch. 1. - Kyyiv, 1998 r. - 180 s.

3. Radul V. Sotsial'na zrilist' molodoho uchytelya / Radul V.// Monohrafiya. - K.: Vyshcha shkola, 1997. - S. 134-144.

4. Konovalova L. Pedahohichnyy protses // Osvita.ua. - 06.07.2012 : [Elektronnyy resurs] : stattya - Rezhym dostupu: http:// osvita.ua/school/manage/teaching/3988/

5. Oliynyk V. Pidvyshchennya kvalifikatsiyi kerivnykiv osvity za dystantsiynoyu formoyu navchannya / Oliynyk V., Bykov V., Hravit V.ta in. / Za zah. red. V.V.Oliynyka. - K.: Lohos, 2006. - 408 s.

6. Polozhennya pro orhanizatsiyu ochno-dystantsiynoho pidvyshchennya kvalifikatsiyi kerivnykh i pedahohichnykh kadriv u Tsentral'nomu instytuti pislyadyplomnoyi pedahohichnoyi osvity / za zah. red. V.V.Oliynyka. - K.: TsIPPO, 2005.

7. Oliynyk V. Kontseptual'ni zasady pidvyshchennya kvalifikatsiyi kerivnykh kadriv profesiyno-tekhnichnykh navchal'nykh zakladiv za ochno-dystantsiynoyu formoyu navchannya / V.Oliynyk, V.Bykov, V.Hravit ta in. // za zah. red. V.V.Oliynyka. K.: TsIPPO, 2007. - $104 \mathrm{~s}$.

8. Lyakhots'ka L. Teoretyko-praktychni pidkhody do kontrolyu uspishnosti pidvyshchennya kvalifikatsiyi pedahohichnykh pratsivnykiv // 10.09.2012: [Elektronnyy resurs] : stattya - Rezhym dostupu: http://zavantag.com/docs/1863/index-29658.html).

9. Stepanova Y. Fyksatsyya peremen v protsesse perepidhotovky // Atryum. - 2004. - \#3. - S. 68-72.

10. Putevodytel' po metodolohyy Orhanyzatsyy, Rukovodstva y Uprav-lenyya: khrestomatyya po rabotam H. P. Shchedrovitskoho. - M. : Delo, 2003. - $160 \mathrm{~s}$.

11. Shchedrovitsky G. Refleksyya y ee problemы/ Shchedrovytskyy H. // Razrabotka y vnedrenye avtomatyzyrovannыkh system v proektyrovanyy (teoryya y metodolohyya). - M.: Stroyyzdat. - 1975. - $385 \mathrm{~s}$. 


\section{IMPROVEMENT OF TEACHERS QUALIFICATIONS}

\section{OLENA DOBROTVOR}

https://doi.org/10.35945/gb.2017.04.013

PhD in Pedagogical Sciences,

Associated Professor of National Aviation University, Institute of the Humanities, Ukraine

KEYWORDS: CONTINUING PROFESSIONAL EDUCATION, ADVANCED TRAINING, TEACHINGS STAFF, REFLECTION

\section{SUMMARY}

The main interest is to seek for and study new approaches to the process of teachers training in accordance with the basic principles of adult learning (andragogy). The article analyzes the forms and methods of teaching which are common practice in the national Ukrainian postgraduate education. Based upon the available sources are summarized theoretical and practical expert recommendations to overcome the existing problems and improve the training system of postgraduate education. As a result of research excellence, including foreign experience (Russia, USA) is presented the hypothesis of necessary and efficient use of specially organized training reflection for productive updates to improve teaching staff training. The concept of "reflection" has been interpreted by the Russian school of methodology of G. Shchedrovitsky as a person's alienated idea of their actions in their own mind. The article suggests the description of the specific methods of organizing reflective attitude to teaching, which provides planning qualitative changes and a record of the results. 